\title{
Histological modifications of the rat prostate following oral administration of silver nanoparticles
}

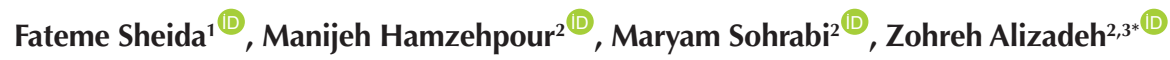 \\ ${ }^{1}$ Student Research Committee, Hamadan University of Medical Sciences, Hamadan, Iran \\ ${ }^{2}$ Department of Anatomical Sciences, Faculty of Medicine, Hamadan University of Medical Sciences, Hamadan, Iran \\ ${ }^{3}$ Endometrium and Endometriosis Research Center, Hamadan University of Medical Sciences, Hamadan, Iran
}

*Corresponding Author: Zohreh Alizadeh, Department of Anatomical Sciences, Faculty of Medicine, Hamadan University of Medical Sciences, Shahid Fahmideh Street, 65178-3-8736, Hamadan, Iran. Tel: +988138276295, FAX: +988138380208, Email: alizadeh@umsha.ac.ir, alizadeh.zohreh@gmail.com

\begin{abstract}
Background and aims: Recently, silver nanoparticles (AgNPs) have received much attention for their possible usage in various fields. This study examined the effect of AgNPs on the histopathological changes in the prostate of rats.

Methods: In this study, 40 male adult Wistar rats were divided into five equal groups ( $n=8$ in each group). AgNPs were given orally to the four experimental groups at doses of 30,125,300, and $700 \mathrm{mg} / \mathrm{kg}$ for 28 consecutive days. The control group received deionized water. After performing hematoxylin and eosin (H\&E) staining and Masson's trichrome staining, the histological changes in the prostate of rats were evaluated.

Results: Histological evaluation showed that the acinar epithelial height and alveolar folds decreased, but vacuoles in the epithelial cells and accumulation of blood vessel increased in the groups treated with AgNPs at doses of 30 and $125 \mathrm{mg} / \mathrm{kg}$. The collagen content also increased significantly in these groups $(30 \mathrm{mg} / \mathrm{kg}: P=0.03$ and $125 \mathrm{mg} / \mathrm{kg}: P=0.002)$. Furthermore, the groups treated with AgNPs at doses of 300 and $700 \mathrm{mg} / \mathrm{kg}$ showed relative normalization acini and epithelial lining and the amount of their content.

Conclusion: According to the results of current study, oral administration of AgNPs for 28 days had effects on prostate, indicating the toxicity of AgNPs.

Keywords: Prostate, Silver nanoparticles, Collagen, Histology, Rat
\end{abstract}

Received: 23 May 2020, Accepted: 12 August 2020, ePublished: 30 March 2021

\section{Introduction}

Nanotechnology is a multidisciplinary scientific field of applications manufactured at the molecular level. Due to its increasing progress, nanotechnology can cause revolutionary advances across such sciences as medicine, communications, genomics, and robotics (1). The extensive use of nanoparticles (NPs) is based on their distinctive chemical and physical properties, such as large surface area, small size, and high reactivity potential (2).

Silver nanoparticles (AgNPs) are one of the most common types of NPs that are widely used in different products including medicine, food industry, textiles, electronics, and pharmaceutical preparations $(3,4)$.

AgNPs can enter the body through different ways, such as injection, inhalation, oral, and dermal route. Since AgNPs are being used in different food products, including water and liquid beverages, nutritional supplements, toothpastes, and drug carriers, the digestive tract is the notable absorption route for them $(4,5)$.

In vitro and in vivo investigations have shown that exposure to AgNPs can lead to inflammatory reaction (6), DNA damage (7), and histological changes in the kidneys, lungs, liver, endocrine, and the male reproductive system (8). There are several studies on the toxic effects of AgNPs on the testis and sperms (9-11). The potential adverse effect of administrating AgNPs orally on the histology of prostate, which is one of the male accessory sex glands, has not been addressed well. Thus, this study aimed to investigate the potential toxic effect of oral subchronic exposure to AgNPs on histology of the prostate in rats.

\section{Material and Methods \\ AgNP solution}

AgNPs in powder form (CAS No. 7440-22-4) was dispersed in deionized water and prepared concentrations of $30,125,300$, and $700 \mathrm{mg} / \mathrm{kg}$ using vigorous vortexing sonication for 5 minutes.

The size distribution of the NPs was analyzed using dynamic light-scattering (DLS; Malvern, Nano ZS ZEN3600, UK).

(C) 2021 The Author(s); Published by Shahrekord University of Medical Sciences. This is an open-access article distributed under the terms of the Creative Commons Attribution License (http://creativecommons.org/licenses/by/4.0), which permits unrestricted use, distribution, and reproduction in any medium, provided the original work is properly cited. 


\section{Administration of AgNPs}

In this study, 40 adult male Wistar rats with weights of 180$200 \mathrm{~g}$ were used. The rats were kept in the animal house under a natural light/dark cycle with standard conditions of $21 \pm 2^{\circ} \mathrm{C}$ and $50 \pm 5 \%$ humidity. The rats were divided into five equal groups (four intervention vs. one control). The four experimental groups were administered orally with 30, 125, 300, and $700 \mathrm{mg} / \mathrm{kg}$ AgNPs for 28 days and the rats in the control group received equal volumes of deionized water. At the end of the treatment period, body weight was measured, and the animals were sacrificed. For histological study, the anterior lobes of prostates were removed and fixed in 10\% neutral buffered formalin.

\section{Histological Study}

Formalin-fixed prostatic tissues were processed routinely, blocked in paraffin after gradient dehydration, sectioned, deparaffinized, and rehydrated. The 5 um sections prepared using the rotary microtome and stained with hematoxylin and eosin (H\&E). Masson's trichrome staining was also used to assess the collagen density. The images for histological examination were obtained through light microscope with video camera (Motic 2003). The ImageJ software was used for the acquisition of the collagen density.

\section{Statistical Analysis}

SPSS software version 16.00 (SPSS Inc., USA) was used for statistical analysis. Data were expressed as means \pm standard error (SE). The results were statistically analyzed using one-way ANOVA with subsequent Tukey's test. To compare the selected pairs of groups, probability level of $<0.05$ was considered as statistically significant.

\section{Results}

\section{Characterization of Silver Nanoparticles}

The AgNPs suspension was analyzed under dynamic light scattering (DLS) for size. The results showed the hydrodynamic diameter in range of 200-300 nm (Figure 1).

\section{Body and Organ Weight}

Table 1 shows the body weight gain and prostate weight.
There were no significant $(P>0.05)$ dose-related changes in the body weight gains and prostate weight in the treated rats compared to the control ones.

\section{Histological study}

\section{H\&E-stained sections}

The histological changes of the prostate gland in the rats administered with AgNPs were analyzed. The results showed that the acinar epithelial height and alveolar folds decreased and the acini lined by flattened epithelium. The vacuoles in the epithelial cells, thickness of muscle fibers, the ratio of parenchyma to stroma, and the blood vessel accumulation were increased in treated rats. Prostate of rats treated with 30 and $125 \mathrm{mg} / \mathrm{kg}$ AgNPs revealed more prominent histological changes compared to the rats treated with 300 and $700 \mathrm{mg} / \mathrm{kg} \mathrm{AgNPs}$ (Table 2 and Figure 2).

\section{Masson's trichrome staining}

Masson's trichrome quantified the intensity of collagen deposition. The collagen intensity increased in the groups treated with AgNPs at the doses of $30 \mathrm{mg} / \mathrm{kg} \quad(P=0.03)$ and $125 \mathrm{mg} / \mathrm{kg}(P=0.002)$ compared to the control. The collagen content was almost similar in normal renal tissues in groups treated with AgNPs at the doses of 300 and 700 $\mathrm{mg} / \mathrm{kg}$ (Figure 3).

\section{Discussion}

AgNPs are used in many food and medical products. Many studies suggest that AgNPs could potentially be toxic (1216). Despite lots of benefits of AgNPs, a dose-dependent

Table 1. Body weight gain and prostate weight of rats after oral treatment with AgNPs for 28 days

\begin{tabular}{lcc}
\hline Group & Body weight gain & Prostate weight (g) \\
\hline Control & $72.72 \pm 19.50$ & $0.54 \pm 0.11$ \\
$30 \mathrm{mg} / \mathrm{kg}$ & $61.02 \pm 8.045$ & $0.32 \pm 0.14$ \\
$125 \mathrm{mg} / \mathrm{kg}$ & $76.63 \pm 18.57$ & $0.45 \pm 0.15$ \\
$300 \mathrm{mg} / \mathrm{kg}$ & $64.52 \pm 7.98$ & $0.65 \pm 0.15$ \\
$700 \mathrm{mg} / \mathrm{kg}$ & $67.05 \pm 2.29$ & $0.58 \pm 0.09$ \\
\hline
\end{tabular}

* No significant difference was seen $(P=0.1)$

Data are expressed as mean \pm SD.

Table 2. Effect of treatment with AgNPs $(30,125,300$, and $700 \mathrm{mg} / \mathrm{kg})$ for 28 days on prostate qualified histological criteria

\begin{tabular}{|c|c|c|c|c|c|}
\hline & Control & $30 \mathrm{mg} / \mathrm{kg}$ & $125 \mathrm{mg} / \mathrm{kg}$ & $300 \mathrm{mg} / \mathrm{kg}$ & $700 \mathrm{mg} / \mathrm{kg}$ \\
\hline Folded secretory alveolar & ++ & - & - & - & + \\
\hline Vacuoles in the epithelial cells & - & + & + & - & - \\
\hline Thickness of muscle fibers & - & +++ & +++ & ++ & + \\
\hline Level of parenchyma to stroma & - & ++ & ++ & + & - \\
\hline Blood vessel accumulation & + & ++ & +++ & +++ & ++ \\
\hline Epithelial heights & + & - & - & + & + \\
\hline Secretory content & + & ++ & +++ & + & + \\
\hline
\end{tabular}

Note. The (-) absent, (+) mild, (++) moderate, and (+++) severe schemes were used to score the histological alterations. 
Size Distribution by Number

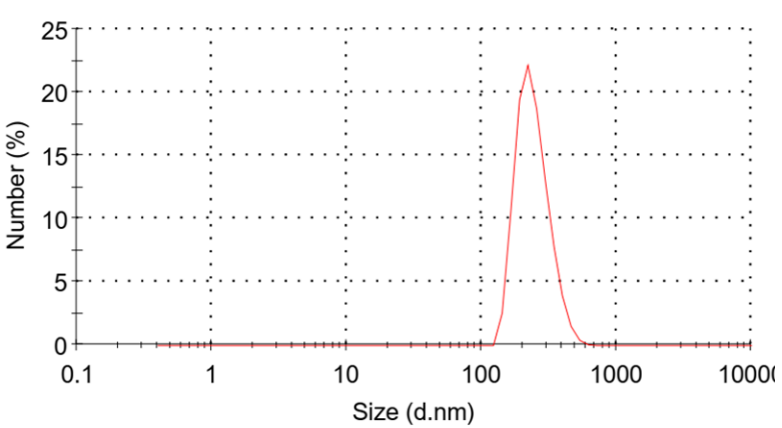

Figure 1. Dynamic light scattering (DLS) results of the characterization of silver nanoparticles.

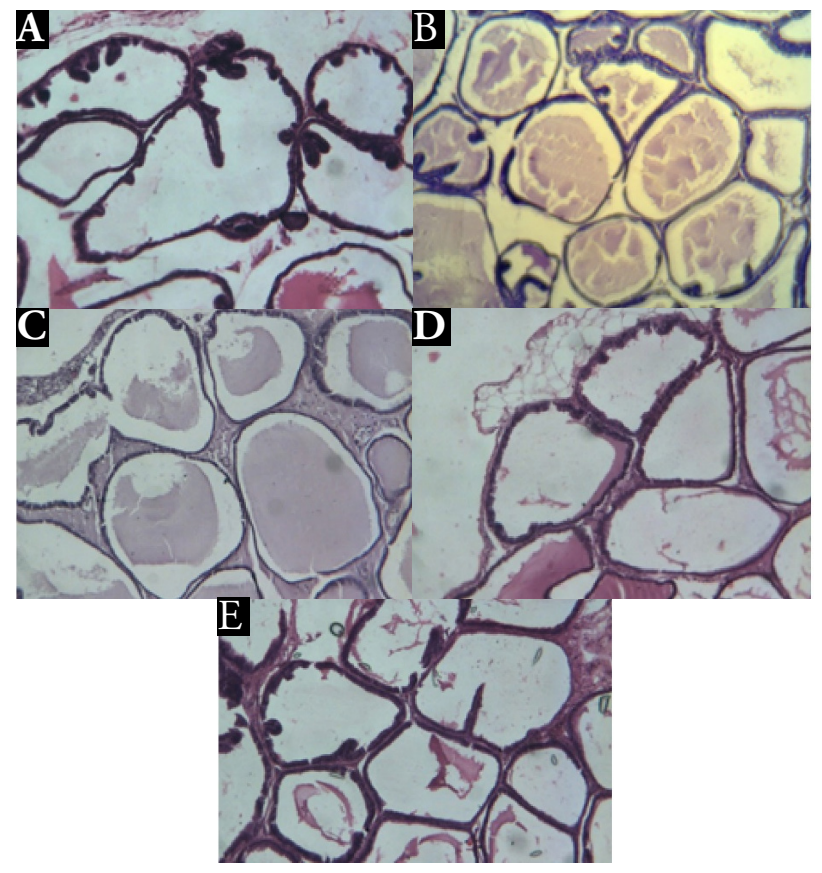

Figure 2. Effect of silver nanoparticle on histology of prostate tissue in rats (H\&E staining $\times 10)$. (A) Control group has normal structure, the acini lined with folded cuboid epithelium, and empty lumen. (B and C) The groups treated with 30 and $125 \mathrm{mg} / \mathrm{kg}$ AgNPs show acini with flattened lining epithelium (the acini with cystic atrophy appearance) and decreased folding and increased secretion in acini. (D and E) The groups treated with 300 and $700 \mathrm{mg} / \mathrm{kg}$ AgNPs show tissue compact acini; the epithelial lining, folding, and contents were relatively the same as control group.

study to monitor impact of AgNPs exposure on animal and human health seems to be necessary. The results of studying biodistribution of AgNPs in rats have shown that they are dose- and size-dependent. The accumulation of AgNPs in different cells, such as reproductive cells, causes changes in sperm parameters (17-20). An in vivo toxicity experiment was performed on Sprague-Dawley rats, orally treated for 28 days with nano-silver by Kim et al at doses of 30,300 , and $1000 \mathrm{mg} / \mathrm{kg}$ per day (17). The current study extended these concentrations with some modification to assess whether AgNPs treated orally can have adverse impacts at prostate of rats.

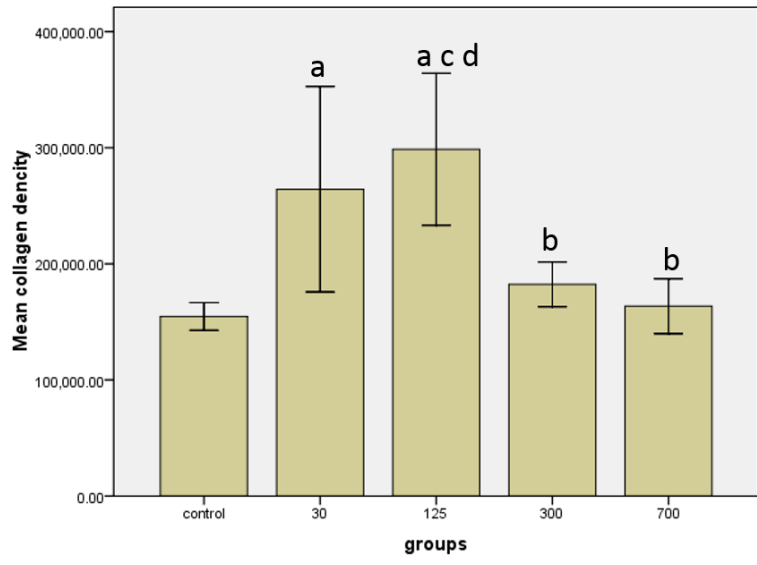

Figure 3. The collagen deposition in prostate of rats treated with $30,125,300$, and $700 \mathrm{mg} / \mathrm{kg}$ concentrations of AgNPs. Data are shown in mean \pm SD. Significant differences shown as: a: compared to control group $(P=002)$, b: to $125 \mathrm{mg} / \mathrm{kg}$ group $(P=0.01), \mathbf{c}$ : to 300 $\mathrm{mg} / \mathrm{kg}$ group $(P=0.007)$. and $\mathbf{d}$ : to $700 \mathrm{mg} / \mathrm{kg}$ group $(P=0.001)$.

There were no significant dose-related changes in the body weight gains and weight of prostate of the rats. These results agree with those of Kim et al (18) that did not show any significant changes in body and prostate weight relative to various concentrations of AgNPs during the 28day experiment by oral and inhalation exposures.

In current study, the histological examinations showed that dose-dependent AgNPs induced lesions in prostate gland. There were increased vacuoles in epithelial cells, the acini lined by flattened epithelium with cystic changes and increased secretory material in their lumina, and widened stroma at doses 30 and $125 \mathrm{mg} / \mathrm{kg}$ AgNPs, while the prostatic alveoli at 300 and $700 \mathrm{mg} / \mathrm{kg}$ showed prostatic tissue with acini and epithelial lining and the contents were relatively the same as control group. The results of this study showed that these changes were more frequent in groups treated with 30 and $125 \mathrm{mg} / \mathrm{kg} \mathrm{AgNPs}$ concentrations, indicating toxicity induction by these doses.

The activity of the prostate was dependent on stimulation by the testicular hormones. It was shown that the prostatic epithelium was very sensitive to androgen deprivation (21). A decrease was detected in testosterone in rats' treatment with AgNPs (22).

Results of this study revealed the marked deposition of collagen within the stroma in the 30 and $125 \mathrm{mg} / \mathrm{kg}$ treated groups. Interstitial tissue fibrosis involves excessive accumulation of collagen fibrils and is a feature of many diseases that progress to chronic prostatic changes (23). NPs can cause induced stress oxidative, which increase glycation of collagen fibers $(24,25)$.

In confirmation of the effect of toxic substances on vacuolar degeneration and acini changes, the results of the effect of non-carcinogenic dose of cadmium (26), carbimazole (27), and different kinds (28-30) of NPs showed almost the same results. 
Regarding vascular alterations, it seems this inflammatory response results from the oxidative stress caused by AgNPs and leads to vascular congestion (31).

Because of the strong oxidation potential, the excessive amounts of reactive oxygen species are induced by NPs. This could result in the destruction of organelle structures and different biomolecules, that finally lead to necrosis and apoptosis $(32,33)$.

The increased activity of the testicular marker enzyme, $\gamma$-Glutamate trans peptidase $(\gamma-G T)$, prostate specific antigen (PAP) (34), increased serum prostate-specific antigen level (PSA) and acyl carrier protein (ACP) might indicate injury of the prostate gland (35). The elevated PSA level probably indicates the disruption of the cellular basement membrane within the prostate gland acini and ducts leading to leakage of PSA into the prostatic parenchyma, and eventually increasing its serum concentration (36).

In addition to morphological changes, some marker changes have also been found in different nanoparticles threatening in prostate $(29,37)$. Recent studies showed an increase in PSA, PAP concentrations, $\gamma-\mathrm{GT}$, and ACP activity after $\mathrm{ZnONPs}$ (37) and nano-sized titanium dioxide treatment (29).

In the present study, it seems that the more sever histological changes in rats administrated by 30 and 125 $\mathrm{mg} / \mathrm{kg}$ concentrations and slight damage in 300 and $700 \mathrm{mg} / \mathrm{kg} / \mathrm{d}$ concentrations are due to translocation of AgNPs into prostate. In addition, it might be due to the agglomeration of AgNPs used in this study $(-250$ $\mathrm{nm}$ hydrodynamic diameter agglomerates). After oral administration, the small intestine is the first site for absorption of NPs. The large agglomeration size of AgNPs in high concentration may also have prevented their intestinal absorption and so resulted in an insufficient amount being available to the prostate. Similar changes were observed by Kim et al (17) and Kulthong et al (38).

\section{Conclusion}

The present study demonstrated that AgNPs induced histological changes in prostate and fibrosis by repeated oral administration.

Conflict of Interests

There is no conflict of interests.

\section{Ethical Approval}

All procedures were approved by the Ethics Committee of Hamadan University of Medical Sciences, Iran (HUMS, IR.UMSHA. REC.1396.597).

\section{Authors' Contribution}

ZA designed the study, analyzed the data, and revised the paper. FS carried out data collection, wrote the manuscript draft. MS contributed to study design participation in analysis. $\mathrm{MH}$ carried out data collection.
Funding/Support

This study was supported by the Vice-chancellor for Research and Technology, Hamadan University of Medical Sciences, Iran (grant no.: 9610056181).

\section{References}

1. Nikolova M, Slavchov R, Nikolova G. Nanotechnology in medicine. In: Hock FJ, Gralinski MR, eds. Drug Discovery and Evaluation: Methods in Clinical Pharmacology. Cham: Springer; 2020. p. 533-46. doi: 10.1007/978-3-319-688640_45.

2. Fazal-ur-Rehman M. Novel applications of nanomaterials and nanotechnology in medical sciences-a review. J Basic Appl Sci Res. 2018;8(4):1.

3. Bartłomiejczyk T, Lankoff A, Kruszewski M, Szumiel I. Silver nanoparticles--allies or adversaries? Ann Agric Environ Med. 2013;20(1):48-54.

4. Burdușel AC, Gherasim O, Grumezescu AM, Mogoantă L, Ficai A, Andronescu E. Biomedical applications of silver nanoparticles: an up-to-date overview. Nanomaterials (Basel). 2018;8(9):861. doi: 10.3390/nano8090681.

5. Hadrup N, Sharma AK, Loeschner K. Toxicity of silver ions, metallic silver, and silver nanoparticle materials after in vivo dermal and mucosal surface exposure: a review. Regul Toxicol Pharmacol. 2018;98:257-67. doi: 10.1016/j. yrtph.2018.08.007.

6. Vijayaraj R, Dinesh Kumar G, Sri Kumaran N. In vitro antiinflammatory activity of silver nanoparticle synthesized Avicennia marina (Forssk.) Vierh.: a green synthetic approach. Int J Green Pharm. 2018;12(3):S528-S36. doi: 10.22377/ijgp. v12i03.2014.

7. Liu F, Mahmood M, Xu Y, Watanabe F, Biris AS, Hansen DK, et al. Effects of silver nanoparticles on human and rat embryonic neural stem cells. Front Neurosci. 2015;9:115. doi: 10.3389/ fnins.2015.00115.

8. Vazquez-Muñoz R, Borrego B, Juárez-Moreno K, GarcíaGarcía M, Mota Morales JD, Bogdanchikova N, et al. Toxicity of silver nanoparticles in biological systems: does the complexity of biological systems matter? Toxicol Lett. 2017;276:11-20. doi: 10.1016/j.toxlet.2017.05.007.

9. Fathi N, Hoseinipanah SM, Alizadeh Z, Assari MJ, Moghimbeigi A, Mortazavi $M$, et al. The effect of silver nanoparticles on the reproductive system of adult male rats: a morphological, histological and DNA integrity study. Adv Clin Exp Med. 2019;28(3):299-305. doi: 10.17219/acem/81607.

10. Castellini C, Ruggeri S, Mattioli S, Bernardini G, Macchioni L, Moretti E, et al. Long-term effects of silver nanoparticles on reproductive activity of rabbit buck. Syst Biol Reprod Med. 2014;60(3):143-50. doi: 10.3109/19396368.2014.891163.

11. Olugbodi JO, David O, Oketa EN, Lawal B, Okoli BJ, Mtunzi F. Silver nanoparticles stimulates spermatogenesis impairments and hematological alterations in testis and epididymis of male rats. Molecules. 2020;25(5):1063. doi: 10.3390/ molecules25051063.

12. Nel A, Xia T, Mädler L, Li N. Toxic potential of materials at the nanolevel. Science. 2006;311(5761):622-7. doi: 10.1126/ science.1114397.

13. Jiménez-Lamana J, Laborda F, Bolea E, Abad-Álvaro I, Castillo JR, Bianga J, et al. An insight into silver nanoparticles bioavailability in rats. Metallomics. 2014;6(12):2242-9. doi: 10.1039/c4mt00200h.

14. Carlson C, Hussain SM, Schrand AM, Braydich-Stolle LK, Hess KL, Jones RL, et al. Unique cellular interaction of silver nanoparticles: size-dependent generation of reactive oxygen species. J Phys Chem B. 2008;112(43):13608-19. doi: 
10.1021/jp712087m.

15. Asare N, Instanes C, Sandberg WJ, Refsnes M, Schwarze P, Kruszewski $\mathrm{M}$, et al. Cytotoxic and genotoxic effects of silver nanoparticles in testicular cells. Toxicology. 2012;291(13):65-72. doi: 10.1016/j.tox.2011.10.022.

16. Marchioni M, Jouneau P-H, Chevallet M, Michaud-Soret I, Deniaud A. Silver nanoparticle fate in mammals: bridging in vitro and in vivo studies. Coord Chem Rev. 2018;364:118-36. doi: 10.1016/j.ccr.2018.03.008.

17. Kim YS, Kim JS, Cho HS, Rha DS, Kim JM, Park JD, et al. Twenty-eight-day oral toxicity, genotoxicity, and genderrelated tissue distribution of silver nanoparticles in SpragueDawley rats. Inhal Toxicol. 2008;20(6):575-83. doi: 10.1080/08958370701874663.

18. Kim YS, Song MY, Park JD, Song KS, Ryu HR, Chung YH, et al. Subchronic oral toxicity of silver nanoparticles. Part Fibre Toxicol. 2010;7:20. doi: 10.1186/1743-8977-7-20.

19. Yang L, Kuang $\mathrm{H}$, Zhang $\mathrm{W}$, Aguilar ZP, Wei $\mathrm{H}, \mathrm{Xu} \mathrm{H}$. Comparisons of the biodistribution and toxicological examinations after repeated intravenous administration of silver and gold nanoparticles in mice. Sci Rep. 2017;7(1):3303. doi: 10.1038/s41598-017-03015-1.

20. Taylor U, Barchanski A, Kues W, Barcikowski S, Rath D. Impact of metal nanoparticles on germ cell viability and functionality. Reprod Domest Anim. 2012;47 Suppl 4:359-68. doi: 10.1111/j.1439-0531.2012.02099.x.

21. Moore RW, Rudy TA, Lin TM, Ko K, Peterson RE. Abnormalities of sexual development in male rats with in utero and lactational exposure to the antiandrogenic plasticizer $\mathrm{Di}(2$-ethylhexyl) phthalate. Environ Health Perspect. 2001;109(3):229-37. doi: 10.1289/ehp.01109229.

22. Baki ME, Miresmaili SM, Pourentezari M, Amraii E, Yousefi V, Spenani HR, et al. Effects of silver nano-particles on sperm parameters, number of Leydig cells and sex hormones in rats. Iran J Reprod Med. 2014;12(2):139-44.

23. Wong L, Hutson PR, Bushman W. Prostatic inflammation induces fibrosis in a mouse model of chronic bacterial infection. PLoS One. 2014;9(6):e100770. doi: 10.1371/ journal.pone.0100770.

24. Wang E, Huang Y, Du Q, Sun Y. Silver nanoparticle induced toxicity to human sperm by increasing ROS(reactive oxygen species) production and DNA damage. Environ Toxicol Pharmacol. 2017;52:193-9. doi: 10.1016/j.etap.2017.04.010.

25. McCarthy AD, Etcheverry SB, Bruzzone L, Lettieri G, Barrio DA, Cortizo AM. Non-enzymatic glycosylation of a type I collagen matrix: effects on osteoblastic development and oxidative stress. BMC Cell Biol. 2001;2:16. doi: 10.1186/1471-21212-16.

26. Alvarez SM, Gómez NN, Scardapane L, Zirulnik F, Martínez D, Giménez MS. Morphological changes and oxidative stress in rat prostate exposed to a non-carcinogenic dose of cadmium. Toxicol Lett. 2004;153(3):365-76. doi: 10.1016/j. toxlet.2004.06.004.

27. Sakr SA, Mahran HA, Nofal AE. Effect of selenium on carbimazole-induced histopathological and histochemical alterations in prostate of albino rats. Am J Med Med Sci. 2012;2(1):5-11. doi: 10.5923/j.ajmms.20120201.02.

28. Mohammed AS, Salman RA, Jafer AJ. The effect of different doses levels of silver nanoparticles (AgNPs) on the seminal vesicles and prostate in Albino male Rat. Histopathological study. Int J Sci Eng Res. 2016;7(3):980-3.

29. Shahin NN, Mohamed MM. Nano-sized titanium dioxide toxicity in rat prostate and testis: possible ameliorative effect of morin. Toxicol Appl Pharmacol. 2017;334:129-41. doi: 10.1016/j.taap.2017.08.014

30. Axiak-Bechtel SM, Upendran A, Lattimer JC, Kelsey J, Cutler CS, Selting KA, et al. Gum arabic-coated radioactive gold nanoparticles cause no short-term local or systemic toxicity in the clinically relevant canine model of prostate cancer. Int J Nanomedicine. 2014;9:5001-11. doi: 10.2147/ijn.s67333.

31. Sun X, Yang Y, Shi J, Wang C, Yu Z, Zhang H. NOX4- and Nrf2mediated oxidative stress induced by silver nanoparticles in vascular endothelial cells. J Appl Toxicol. 2017;37(12):142837. doi: 10.1002/jat.3511.

32. Yu Z, Li Q, Wang J, Yu Y, Wang Y, Zhou Q, et al. Reactive oxygen species-related nanoparticle toxicity in the biomedical field. Nanoscale Res Lett. 2020;15(1):115. doi: 10.1186/ s11671-020-03344-7.

33. Maurer LL, Meyer JN. A systematic review of evidence for silver nanoparticle-induced mitochondrial toxicity. Environ Sci Nano. 2016;3(2):311-22. doi: 10.1039/c5en00187k.

34. Kawakami K, Fujita Y, Matsuda Y, Arai T, Horie K, Kameyama $\mathrm{K}$, et al. Gamma-glutamyltransferase activity in exosomes as a potential marker for prostate cancer. BMC Cancer. 2017;17(1):316. doi: 10.1186/s12885-017-3301-x.

35. Kong HY, Byun J. Emerging roles of human prostatic acid phosphatase. Biomol Ther (Seoul). 2013;21(1):10-20. doi: 10.4062/biomolther.2012.095.

36. Mattsson JM, Ravela S, Hekim C, Jonsson M, Malm J, Närvänen A, et al. Proteolytic activity of prostate-specific antigen (PSA) towards protein substrates and effect of peptides stimulating PSA activity. PLoS One. 2014;9(9):e107819. doi: 10.1371/ journal.pone.0107819.

37. Nazem H, Arefian Z. Effect of ZnO NPs on tumor marker hormones in male rats. Biomed Res. 2015;26(1):82-8

38. Kulthong K, Maniratanachote R, Kobayashi Y, Fukami T, Yokoi T. Effects of silver nanoparticles on rat hepatic cytochrome P450 enzyme activity. Xenobiotica. 2012;42(9):854-62. doi: 10.3109/00498254.2012.670312. 